OPEN ACCESS

Edited by:

Gianni Parise,

McMaster University, Canada

Reviewed by:

Dario Coletti,

Sapienza University of Rome, Italy Charikleia Stefanaki,

National and Kapodistrian University of Athens, Greece

*Correspondence:

Nicholas A. Burd naburd@illinois.edu

Specialty section:

This article was submitted to Clinical Nutrition,

a section of the journa Frontiers in Nutrition

Received: 10 October 2020 Accepted: 01 March 2021 Published: 05 May 2021

Citation:

Paulussen KJM, McKenna CF Beals JW, Wilund KR, Salvador AF

and Burd NA (2021) Anabolic Resistance of Muscle Protein Turnover Comes in Various Shapes and Sizes.

Front. Nutr. 8:615849.

doi: 10.3389/fnut.2021.615849

\section{Anabolic Resistance of Muscle Protein Turnover Comes in Various Shapes and Sizes}

\author{
Kevin J. M. Paulussen ${ }^{1}$, Colleen F. McKenna ${ }^{2}$, Joseph W. Beals ${ }^{3}$, Kenneth R. Wilund ${ }^{1,2}$, \\ Amadeo F. Salvador ${ }^{1}$ and Nicholas A. Burd ${ }^{1,2 *}$ \\ ${ }^{1}$ Department of Kinesiology and Community Health, University of Illinois at Urbana-Champaign, Urbana, IL, United States, \\ ${ }^{2}$ Division of Nutritional Sciences, University of Illinois at Urbana-Champaign, Urbana, IL. United States, ${ }^{3}$ Center for Human \\ Nutrition, Washington University School of Medicine, St. Louis, MO, United States
}

Anabolic resistance is defined by a blunted stimulation of muscle protein synthesis rates (MPS) to common anabolic stimuli in skeletal muscle tissue such as dietary protein and exercise. Generally, MPS is the target of most exercise and feeding interventions as muscle protein breakdown rates seem to be less responsive to these stimuli. Ultimately, the blunted responsiveness of MPS to dietary protein and exercise underpins the loss of the amount and quality of skeletal muscle mass leading to decrements in physical performance in these populations. The increase of both habitual physical activity (including structured exercise that targets general fitness characteristics) and protein dense food ingestion are frontline strategies utilized to support muscle mass, performance, and health. In this paper, we discuss anabolic resistance as a common denominator underpinning muscle mass loss with aging, obesity, and other disease states. Namely, we discuss the fact that anabolic resistance exists as a dimmer switch, capable of varying from higher to lower levels of resistance, to the main anabolic stimuli of feeding and exercise depending on the population. Moreover, we review the evidence on whether increased physical activity and targeted exercise can be leveraged to restore the sensitivity of skeletal muscle tissue to dietary amino acids regardless of the population.

Keywords: sarcopenia, obesity, chronic kidney disease, dietary protein, exercise

\section{INTRODUCTION}

In healthy individuals aged $\sim 18-50$, who are not sedentary and eat sufficient daily amounts of protein and energy, the amount of skeletal muscle mass remains relatively unchanged throughout daily life (1). The maintenance of skeletal muscle mass is achieved by a daily net protein balance between muscle protein synthesis rates (MPS) and muscle protein breakdown rates (MPB). In contrast, skeletal muscle proteins are irreversibly lost with negatively imbalanced protein turnover, as observed with aging and catabolic pathologies. Muscle protein loss can occur as a result of increased MPB or reduced MPS (or by some combination of the two). However, it is believed that a desensitization of MPS to normal anabolic stimuli, such as feeding and exercise, may be the main culprit underpinning the age and disease-related decline in muscle quantity or quality $(2,3)$. This desensitization of MPS to normal anabolic stimuli, has also been shown in patients with kidney failure receiving maintenance hemodialysis (MHD), possibly due to their muscles being overstimulated (hyper-protein metabolic) from treatment (4). Finally, injury or illness leading 
to muscle disuse negatively influences post-absorptive MPS (5) and attenuates the postprandial anabolic response to protein ingestion in otherwise healthy young individuals $(5,6)$.

It is evident that anabolic resistance has been detected in a number of conditions with different etiologies and is often regarded as the underlying cause of muscle mass loss. This ultimately affects physical performance and whole-body health given that the amount and quality of skeletal muscle regulates muscle strength and power, glucose disposal, fat oxidation, and energy balance $(7,8)$. As such, it is imperative to develop treatment strategies for anabolic resistance to minimize disease risk, retain independence, and ensure active involvement in family and community life. In this review, we discuss dietary and exercise considerations to both delay the onset of and minimize the negative consequences of anabolic resistance of muscle across pathologies. What is noteworthy is that the term "anabolic resistance" is often used to describe a decrease in the quality or quantity of a particular muscle protein pool, namely the myofibrillar proteins as opposed to the other protein subfractions (i.e., sarcoplasmic, mitochondrial, or collagen proteins). While anabolic resistance of myofibrillar protein synthesis rates is a common characteristic of aging and other compromised patient conditions, the underpinning mechanisms that are driving this poor responsiveness of contractile proteins to dietary amino acid availability in circulation are different between them. Therefore, the aim of this paper is to highlight the point that anabolic resistance manifests in different ways depending on the underlying etiology (Figure 1). We primarily focus on protein nutrition as this macronutrient has the strongest anabolic action on skeletal muscle tissue and, as such, appears to be the most susceptible macronutrient to anabolic resistance with aging and the various discussed clinical settings.

\section{PROTEIN TURNOVER IN HEALTHY MUSCLE}

In healthy muscle, the consumption of isolated protein stimulates an increase of MPS in a dose-response manner $(14,15)$, with excess dietary amino acids being catabolized as opposed to utilized for postprandial MPS (15). The plateau of this dose-response curve has been shown to occur at $\sim 0.25 \mathrm{~g}$ protein/kg body mass/meal in healthy young adults (9). The responsiveness of the postprandial muscle protein synthetic response is enhanced with the performance of resistance exercise, but not endurance exercise (16), prior to protein ingestion (17, 18). Based on the speed of amino acid absorption in relation to the stimulation of postprandial MPS, it has been shown that the ingestion of certain sources of isolated protein are more anabolic than others (e.g., whey $>$ casein) $(19,20)$. Moreover, the amino acid composition of the ingested isolated protein source also has been shown to be an anabolic factor for the stimulation of MPS (20). In particular, the leucine content $(21,22)$, and the associated leucinemia (23), of the isolated protein source has been shown to potentiate postprandial MPS. Leucine is an anabolic signaling molecule acting through both mTORC1-dependent (24) and mTORC1-independent mechanisms (25) as well as a substrate to support the stimulation of MPS (26). While leucine serves both as a building block and signal, it is important to remember that all essential amino acids need to be available in order to maximize the anabolic potential of leucine on $\operatorname{MPS}(27,28)$.

Historically, muscle protein metabolism investigations emphasize isolated sources of dietary protein, but it has become increasingly evident that protein foods are greater than the sum of their constituent amino acids for the regulation of postprandial MPS (29). This is likely due to food matrix (i.e., mixed macronutrients, micronutrients, and other bioactive molecules) effects facilitating a more anabolic molecular environment (30) and ultimately potentiating the use of dietary amino acids (including leucine) for postprandial MPS (31). Overall, whole protein foods provide the basis for healthy eating patterns with an option of ingesting isolated protein supplements to facilitate adequate total intake and assist with dietary protein distribution. The latter is believed to modulate daily net whole body (32) and muscle protein accretion (33).

In contrast to MPS, MPB appears to be less sensitive to changes in dietary amino acid availability. For example, MPB is elevated in the recovery period of both resistance and endurance exercise $(34,35)$, but these rates are not modifiable by dietary protein ingestion when compared to post-exercise MPS in healthy adults $(18,36)$. Therefore, nutritional strategies that target MPS, rather than MPB, can effectively achieve a desirable muscle protein balance (37) which additionally supports exercise training adaptations. Other factors such as eating below energy requirement (38), reduced daily carbohydrate intake (39), and habitually high protein intakes (40-42) can modulate dietary protein utilization, highlighting the value of achieving recommended nutrient intakes in relation to recommended energy intake (i.e., diet quality) to support optimal muscle adaptations. It is important to note that skeletal muscle is a heterogeneous tissue and is composed of a variety of different muscle protein pools such as myofibrillar, sarcoplasmic, mitochondrial, and collagen protein fractions. The myofibrillar proteins, which namely consist of actin and myosin, are the predominate protein pool within skeletal muscle tissue and account for $\sim 60-65 \%$ of all muscle proteins. Myofibrillar proteins have a high nutrient sensitivity and thus have a substantial contribution to the stimulation of postprandial mixed MPS and preservation (or growth) of muscle mass throughout adult life $(43,44)$. Collectively, these observations provide the preliminary nutritional framework to support optimal skeletal muscle tissue anabolism. However, adverse alterations in muscle nutrient sensitivity evident with age, body adiposity, catabolic pathologies, and muscle injury or disuse, hinder the anabolic potency of dietary protein.

\section{AGE-RELATED ANABOLIC RESISTANCE}

Several studies have shown no detectable differences in postabsorptive MPS between younger and older men $(9,45,46)$ and women (47). It has been shown, however, that there is a decreased response of MPS to protein ingestion in older adults when compared to their younger counterparts $(9,45,48)$. Recent work 


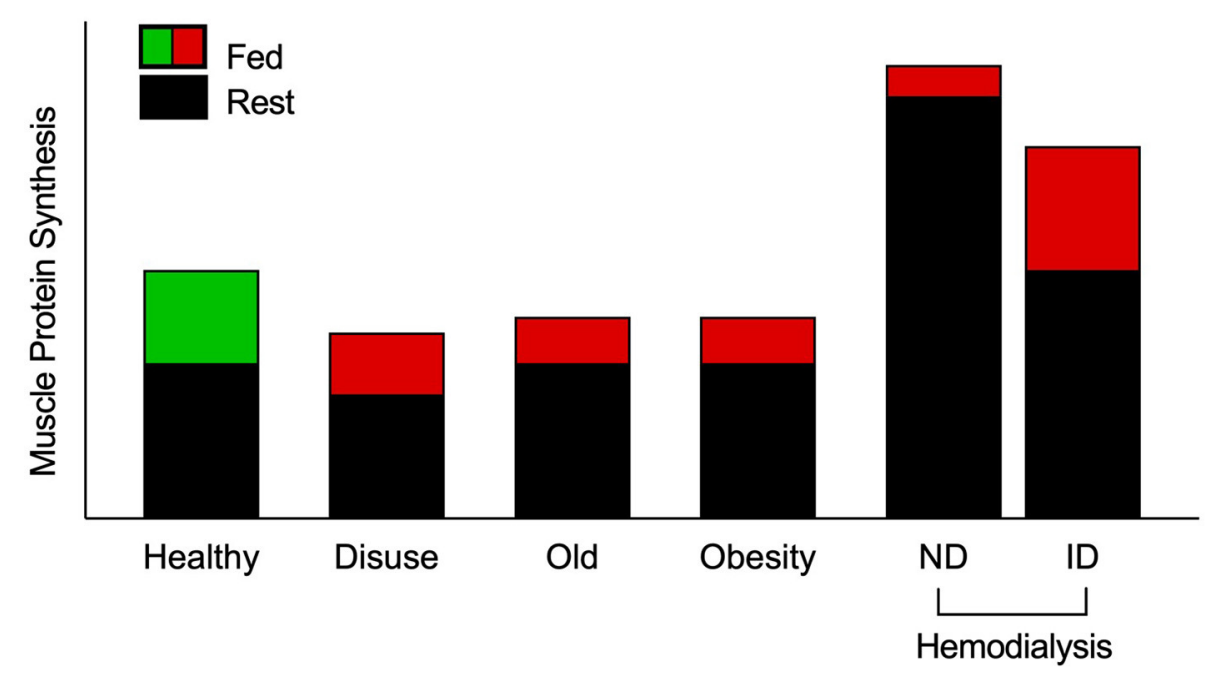

FIGURE 1 | Schematic of muscle protein synthesis rates (MPS) in the basal and postprandial states. Eating a protein meal generally results in a $\sim 2$-fold increase in the stimulation of postprandial MPS from basal in healthy muscle. However, a reduced responsiveness of postprandial MPS, or anabolic resistance, to elevated plasma amino acid availability has been detected in older, obese, and adults on maintenance hemodialysis (MHD) (3, 4, 9-13). Muscle disuse is also a common facilitator of anabolic resistance. Hemodialysis patients have been studied on both dialysis and non-dialysis days. Despite peak inflammation (and presumably catabolism) during dialysis, MPS has been shown to be responsive to intravenous elevation of amino acid availability. However, skeletal muscle is overstimulated in the post-absorptive state on a non-dialysis day, which is associated with inflammation and uremic toxins, to induce overt anabolic resistance. Green indicates "healthy" fed-state MPS response, red indicates anabolically resistant fed-state MPS response. ND, non-dialysis day; ID, intra-dialytic.

has shown a $\sim 10 \%$ reduction in dietary protein digestion and absorption kinetics after protein ingestion with older vs. younger people (49), which likely contributes to age-related anabolic resistance of MPS (46). Such findings have been the impetus behind the development of strategies that target the postprandial period to attenuate age-related muscle mass loss as opposed to post-absorptive MPS. These dietary strategies have included meal fortification with free leucine (50), increasing the relative protein content of each meal $(51,52)$, manipulation of food texture (53), omega-3 supplementation (54), or a combination of various ingredients (55); all of which have shown promise for enhancing the acute postprandial MPS in aging muscle. Beyond these discrete, isolated meal manipulations, it is believed that daily meal frequency may also be an important variable that modulates $24 \mathrm{~h}$ net protein balance and, in extension, the maintenance of muscle mass with advancing age. For example, and similar to young muscle, a spread distribution pattern of protein intake (i.e., moderate, consistent amounts of protein at each meal) throughout the day is effective in maximizing the anabolic potential of each mealtime $(33,56)$. Considering this spread distribution pattern and higher protein requirement per meal, it seems that protein intakes for older adults are likely higher than the current recommended dietary allowance (RDA) in the United States or population reference intake (PRI) from the European Union, of $\sim 0.8 \mathrm{~g} / \mathrm{kg} / \mathrm{d}$ and will be closer to $\sim 1.2$ $\mathrm{g} / \mathrm{kg} / \mathrm{d}$ (or higher). This notion is supported by previous studies using the indicator amino acid oxidation technique showing a safe intake of $\sim 1.25 \mathrm{~g} / \mathrm{kg} / \mathrm{d}$ in adults aged 65 years and older (57). Another study observed that lean body mass loss over 3 years is lowest in older adults consuming $\geq 1.2 \mathrm{~g} / \mathrm{kg} / \mathrm{d}$ (58). All of this, however, is not completely surprising given that the protein $\mathrm{RDA}$ is set to meet the basic nutrient requirement as opposed to optimizing muscle mass with aging. Moreover, recent work has shown that the dietary leucine requirement for older adults is $78.5 \mathrm{mg} \cdot \mathrm{kg}^{-1} \cdot \mathrm{day}^{-1}$, which is more than double the RDA, currently established at $34 \mathrm{mg} \cdot \mathrm{kg}^{-1} \cdot \mathrm{day}^{-1}$ (59). This finding is pertinent as they suggest protein quality is likely another important factor for aging muscle. Specifically, higher quality food proteins are generally higher in leucine by total amino acid content and, as such, provide a more potent anabolic signal to skeletal muscle tissue. Overall, these observations show that dietary protein, and perhaps protein quality, can be a modifiable variable in diminishing the effects of anabolic resistance of MPS in an older population.

Age-associated anabolic resistance is not only associated with an impaired postprandial release of dietary amino acids into the circulation and a reduced responsiveness of MPS to protein ingestion, but it is also pervasive during recovery from both resistance- (60) and endurance-based exercise (61). Fortunately, exercise-specific strategies have been shown to effectively combat the age-related dietary amino acid insensitivity of MPS. For example, pre-conditioning strategies that enhance skeletal muscle capillarization (e.g., endurance training) prior to engaging in regular resistance exercise may be another strategy to enhance hypertrophic protein remodeling in older adults (62, 63). Also, there is some evidence to suggest that higher exercise volume might be associated with higher increases in lean body mass $(60,64,65)$. While modification of the exercise prescription for an older adult may be necessary to robustly stimulate postexercise MPS (66), it is clear that targeted exercise prior to protein 
ingestion improves aged-muscle nutrient sensitivity, leading to postprandial MPS comparable to young adults (17). For example, the anabolic effect of protein ingestion seems to be enhanced in older individuals as Pennings et al. showed that exercise performed prior to $20 \mathrm{~g}$ casein ingestion leads to no difference in post-exercise MPS between the young and old (17).

Ultimately, there appears to be a resistance to anabolic stimuli that potentially can be reversed by increasing doses of both protein ingestion ( $\uparrow$ anabolic signal) and prior exercise $(\uparrow$ dietary amino acid sensitivity of muscle throughout recovery). Specifically, protein intake should be increased above the current RDA or PRI to be closer to $\sim 1.2 \mathrm{~g} / \mathrm{kg} / \mathrm{d}$. Exercise, resistance exercise in particular, seems to drastically increase the dietary amino acid sensitivity of older muscle to protein ingestion. Furthermore, as sedentary lifestyle behavior likely further exacerbates these effects, hence it is advisable to increase daily activity outside of leisure exercise.

Physical inactivity and the prolonged unloading of skeletal muscle tissue can play a significant role in the age-related loss of muscle mass. Indeed, sarcopenia is usually coupled with sedentary lifestyle behaviors during the aging process that can be attenuated with increased habitual physical activity $(67,68)$. In support, when assessing cumulative MPS in free living conditions by the use of deuterated water, Brook et al. demonstrated no differences in older individuals with higher-than-average activity levels when compared to young adults (69). When losing muscle mass at an older age, this is often further exacerbated by a diminished muscle re-growth in older individuals when compared to their younger counterparts after a period of muscle disuse (70) and going through these periods of "catabolic crises" may play a significant role in the loss of muscle mass during aging (71). The latter represents an active area of research whereby various strategies (e.g., neuromuscular stimulation, massage, etc.) are being tested and developed to attenuate muscle mass loss during injury/surgery that requires bedrest. Fortunately, it has been established that regular exercise at a more advanced age leads to an improvement of muscle protein remodeling by enhancing the postprandial MPS to protein ingestion. Hence, it is imperative for older adults to exercise (ideally incorporate some form of strength training) and adhere to healthy eating patterns (choosing nutrient-rich, whole foods) to stave off anabolic resistance as well as maximize skeletal muscle mass both in terms of quantity and quality to better handle an unforeseen catabolic crisis.

\section{OBESITY-RELATED ANABOLIC RESISTANCE}

It is recognized that obesity, regardless of age, can impair the responsiveness of MPS to common anabolic stimuli (i.e., exercise and protein ingestion) compared with the response in sedentary healthy weight individuals (2, 3, 72-75). Indeed, several groups have attempted to investigate postprandial MPS in people with obesity with mixed results $(2,3,72-78)$. Assessments of MPS to ingestion of protein-dense foods have shown that people with obesity have reduced stimulation of myofibrillar $(3,74)$, but not mitochondrial protein synthesis rates (76), compared with healthy-weight individuals. Similar to those experiments, work using intravenous delivery of amino acids (AA) and insulin also showed that people with obesity have lower rates of mixed muscle (72), myofibrillar (73), and mitochondrial (72) protein synthesis under those conditions when compared to non-obese controls. However, comparatively few studies have reported no differences in postprandial MPS between obese and control groups $(75,77,78)$. Altogether, these studies indicate that postprandial stimulation of MPS is impaired in people with obesity and may relate to various metabolic changes (79). This impaired postprandial muscle protein remodeling with obesity likely impacts muscle metabolic quality as opposed to overall "bulk" muscle mass when considering lean body mass is generally the same (or greater) in obese vs. healthy weight individuals.

While older adults and obese individuals are both presented with anabolic resistance, the pathology behind this shared response (or lack thereof in more active aging muscle) is distinct between the two phenotypes. In direct contrast with aged muscle, whereby signaling protein content is lower than the young (45), obese individuals seem to have an overabundance of basal content and phosphorylation of intramuscular anabolic signaling proteins (e.g., mTORC1, p70S6K), which may uniquely inhibit the postprandial anabolic response in the presence of AA availability $(2,3,75,80)$. It is important to note that of the efforts thus far, none have directly compared muscle protein turnover with age-related sarcopenia, sarcopenic-obesity, and non-frail obesity. Of the obese individuals studied, the majority are young/middle-aged adults, with greater lean mass than their lean controls, and otherwise no mention of sarcopenia $(2,3$, 72, 75-78). Similarly, investigations in older adults with obesity either observed comparable lean mass (74) or lack of evidence to classify as sarcopenic-obesity (73). More research is needed to understand the interplay between age-related sarcopenia and excess body adiposity on skeletal muscle regulation.

Outside the context of anabolic resistance, the frontline of obesity treatment involves lifestyle changes to improve body composition and reduce overall body mass, which requires achieving a negative energy balance through either dietary calorie restriction, increased energy expenditure, or a combination of these approaches. However, the loss of lean tissue with weight loss can undermine the maintenance or continuation of weight loss due to reduced metabolic rate $(81,82)$. Structured exercise is a fundamental strategy that simultaneously improves body composition and offsets weight loss-induced decrements in resting metabolic rate in people with obesity $(82,83)$. Exercise programs can largely be distinguished as endurance or resistance exercise training. In healthy young men, acute endurance exercise favors the stimulation of mitochondrial MPS during the postprandial period $(16,84)$, whereas resistance exercise tends to increase myofibrillar MPS (84). These findings suggest a targeted exercise prescription for individuals with obesity, given that anabolic resistance with obesity appears to specifically affect myofibrillar protein synthesis $(2,3,73,74,77)$ more so than muscle mitochondrial protein synthesis $(72,75,76)$.

The impact of acute resistance exercise on MPS and related anabolic signaling mechanism in people with obesity, however, 
is not clear $(2,85)$. One group observed no differences in fasted post-exercise MPS or anabolic signaling molecule phosphorylation (e.g., mTORC1) between obese and healthyweight adults after a single bout of acute resistance exercise (85). More importantly, we have reported that a similar bout of resistance exercise did not augment the myofibrillar protein synthetic response or anabolic signaling after protein ingestion in obese participants compared to a healthy-weight control group (2). This observation further supports an apparent distinction between the anabolic resistance observed with aging and with obesity, as older individuals and young counterparts are conversely sensitized to the anabolic potential of dietary AA after resistance exercise (17).

While a mechanistic understanding of anabolic resistance to traditional stimuli warrants further investigation, interventional outcomes offer more conclusive recommendations. Ensuring an adequate intake of high-quality dietary protein $(>1.2$ $\mathrm{g} / \mathrm{kg} /$ day) helps to preserve myofibrillar protein synthesis during pronounced short-term calorie restriction ( $\sim 40 \%$ energy restriction) at rest $(86,87)$ and with resistance exercise in overweight or obese individuals (87). Additionally, the combination of dietary protein and resistance exercise may also be required for favorable metabolic adaptations to weight loss. Caloric-restriction investigations that manipulate dietary protein intake without concurrent exercise participation observe that weight loss-induced improvements in insulin-stimulated glucose disposal are blunted with higher protein diets $(\sim 1.2$ $\mathrm{g} / \mathrm{kg} /$ day) despite specific advantages of lean mass retention (88). These observations emphasize the need to consider both protein nutrition and intentional exercise when designing interventions to treat obesity.

Obesity is a variable condition with many phenotypes and is likely at the root of various observations discussed throughout this review. In all, the treatment of obesity is challenging and requires monitoring of not only body composition, but also comorbid conditions that may negatively respond to some types of treatment. It is clear that weight loss alone can provide some metabolic benefit in terms of glucose metabolism, but whether long-term maintenance of weight lost and associated benefits requires greater protein intake needs more work, including longer-term interventions and follow-up. Nevertheless, it is clear that weight loss interventions should include an exercise component (with specific emphasis on resistance training) to alleviate lean body mass loss and increase dietary protein utilization.

\section{ANABOLIC RESISTANCE WITH CATABOLIC DISEASES}

As previously described, there is a plethora of evidence to strongly support that the insidious pathology of aging or excess adiposity both result in the anabolic resistance of skeletal muscle. Therefore, it is unsurprising that more overt perturbations in human health also negatively impact muscle response to integral stimuli that support metabolic and physical capacity. Individuals with terminal diagnoses often exhibit aberrant and relentless (i.e., unresponsive to clinical nutrition support) muscle wasting, which is associated with poor quality of life and increased mortality (89).

Cancer, for example, may progress to a cachectic state that is characterized by pervasive catabolism and irreversible losses of muscle mass (90). Hence, there is a clear disruption of net protein balance that likely results from a reduced postabsorptive MPS (91), elevated MPB (92), and/or a postprandial anabolic resistance of MPS (92). Despite this anabolic resistance of fed-state MPS with cancer cachexia, targeted dietary support may show promise in this population. For example, a highprotein $(40 \mathrm{~g})$ nutritional beverage has been shown to overcome anabolic resistance when compared to the ingestion of a standard supplement ( $24 \mathrm{~g}$ casein protein) in cancer cachexia patients (93). In addition to a higher protein content $(24 \mathrm{~g}$ casein fortified with whey protein, free amino acids, and free leucine) than control, this particular treatment beverage also contained EPA and DHA. These omega-3 fatty acids have been shown to enhance MPS (54). Indeed, further research is needed to delineate the contributions of each bioactive constituent to the stimulated postprandial MPS and ultimately for the development of a more anabolic clinical feeding formula. Furthermore, no empirical data to date exist on the magnitude and potential amelioration of anabolic resistance of MPS in cachectic cancer patients.

Muscle wasting is not only observed in malignant disease states but is also present with organ failure, most notably renal failure. End-stage renal disease (ESRD) is often a result of chronic disease (e.g., hypertension, diabetes) progression, thus accompanied by other co-morbid pathologies. In the absence of a kidney transplant, ESRD patients require chronic dialysis, typically in the form of intermittent (i.e., every 48-72 h) hemodialysis (MHD) therapy, to survive. MHD is an imperfect treatment, particularly in the context of protein metabolism, as one treatment session removes up to $15 \mathrm{~g}$ of circulating amino acids (94). This observation supports previous efforts that showed a net negative protein balance in skeletal muscle with MPB exceeding MPS after MHD treatment $(95,96)$. Intradialytic feeding is a therapeutic opportunity to combat these observed imbalances in nutrient handling and net losses of functional body mass in MHD patients. Both intradialytic parental nutrition (IDPN) (97) and oral supplemental nutrition (ONS) $(10,98)$ have been shown to successfully improve plasma amino acid availability and shift acute whole-body and muscle protein balance from negative to positive. However, feeding-induced positive protein balance is sustained in the post-MHD phase only with oral administration (10). Clinical relevance of these acute observations has been investigated: ONS is associated with reduced mortality in retrospective analyses (99-101), and improved serum albumin and prealbumin in a prospective investigation (102). However, these longitudinal analyses are not without limitations, including treatment adherence (compliance affecting feasibility) and the intrinsic flaws of measured parameters like BMI (does not account for lean mass) and serum albumin (negative acute-phase protein). Conversely, investigations outside of the dialysis treatment window may provide insight on the potential of targeted 
exercise and feeding strategies on the stimulation of muscle protein accretion in individuals with ESRD on MHD, especially given MHD patients spend the majority of their time outside the dialysis clinic. Interestingly, we have shown the hyperstimulation of post-absorptive myofibrillar protein synthesis rates, which is driven by enhanced MPB, in MHD patients on non-dialysis days in comparison to age- and BMI-matched controls (4). Furthermore, the ingestion of a mixed meal, which contained $\sim 20 \mathrm{~g}$ protein, resulted in impaired postprandial release of dietary leucine into the circulation, which was insufficient to induce stimulation of the postprandial myofibrillar protein synthetic response in MHD patients, despite adequately stimulating MPS in controls. Hence, there appears to be a twopronged problem contributing to anabolic resistance in patients receiving dialysis treatment (i.e., hyper-stimulated basal muscle protein turnover and impaired protein digestion/absorption kinetics). Nonetheless, an unresolved question arises from this work: how do you fix it? We believe a logical starting point is to reduce the inflammatory and/or uremic milieu to ultimately reduce basal muscle protein turnover in MHD patients (103). The latter will perhaps allow for dietary amino acids to properly act as anabolic signaling molecules and substrates for the stimulation of postprandial MPS in individuals on MHD. This anabolic resistance related to the over stimulation of basal muscle protein turnover is likely underpinning the ineffectiveness of targeted exercise strategies in this patient population as well (104). In fact, Draicchio et al. (105) also demonstrated that there are clear disruptions in proteins associated with the extracellular matrix in patients on MHD, which likely is another contributing factor to the poor mechanotransduction of exercise signals to the muscle protein synthetic machinery. There is likely some level of anabolic resistance in the muscle of even the healthiest of MHD patients, and this is likely exacerbated in patients with overt wasting or sarcopenic obesity. So, it is critically important to attenuate muscle wasting in as many MHD patients as possible in order to maintain an adequate quality of life while in dialysis, to keep patients healthy enough to maintain transplant eligibility, and to improve prognosis following transplant. Importantly, the nephrology field has acknowledged the current short-comings of exercise prescription for MHD patients and have developed working groups (e.g., the Global Renal Exercise Working Group [GREX]) (106) to provide a sounding board for researchers in this field and, as such, improve the efficacy of exercise and nutritional interventions in this patient group.

\section{PHYSICAL INACTIVITY AND MUSCLE DISUSE: A COMMON DENOMINATOR}

The old adage of "use it or lose it" is blatantly accurate as it relates to muscle mass loss with disuse regardless of age or disease state. Specifically, the term disuse describes a spectrum of behavior from reduced habitual physical activity to whole-body disuse. This includes complete disuse, like immobilization or bedrest, which can lead to a decrease in skeletal muscle mass and strength. But also more modest reductions in physical activity that can lead to decrease nutrient sensitivity and a lower muscle anabolic response (67).

It has been well-established that a prolonged period of disuse can lead to a rapid loss of total skeletal muscle mass and strength (107). More recently, it has also been shown that a period of short-term disuse can lead to dramatic losses of skeletal muscle mass and strength (11). Van Loon's research group observed that 2 weeks of one-legged immobilization impaired the MPS response to the ingestion of $20 \mathrm{~g}$ protein in healthy young men, and this led to an $\sim 8.5 \%$ decrease in muscle CSA $(=350 \mathrm{~g}$ of lean tissue) (11). This resembles previous studies that show a general atrophy rate of $0.5-0.6 \%$ per day during a short period of disuse (108). In the study, 2 weeks of disuse led to a $\sim 25 \%$ loss of muscle strength, rapidly decreasing both muscle mass and quality. Looking at even shorter periods of disuse, the same research group has shown that after 5 days of single leg immobilization subjects lost $3.9 \pm 0.6 \%$ CSA of the immobilized leg when compared to the control leg. Furthermore, the researchers showed a decrease in post-absorptive MPS and, more interestingly, despite an increase in circulating plasma insulin and leucine, a decrease in post-prandial MPS in all participants (109). More recently, it has been confirmed that this decreased MPS is sustained throughout the day in free-living conditions during a 7-day period of disuse (110). Hence, a short period of disuse can lead to a rapid onset of anabolic resistance in otherwise healthy young men.

While a complete cessation of movement has a considerable impact on skeletal muscle mass and strength, even a decrease of daily activity can have substantial effects on the anabolic capacity of the muscle. For example, 2 weeks of reduced activity reduces anabolic sensitivity to protein ingestion as observed by Breen et al. (67). In this study, otherwise healthy older adults reduced their daily step-count by $\sim 76 \%$ to $1,413 \pm 110$ steps per day. Postprandial insulin sensitivity decreased by $\sim 43 \%$ and postabsorptive insulin resistance increased by $\sim 12 \%$. Postprandial MPS decreased by $\sim 26 \%$ after the intervention, whereas postabsorptive MPS stayed the same. In comparison, the study from van Loon's group used a model whereby the volunteers received a full leg cast for the same time period of 2 weeks. After the study period, postprandial mixed MPS decreased by $\sim 31 \%$. Additional work on a reduction of physical activity was done by McGlory and colleagues (111). In this study, the researchers confirmed that 2 weeks of step reduction leads to a decrease in insulin sensitivity and an increase in insulin resistance. In addition, McGlory et al. (111) provided an important extension to these findings showing a $\sim 35 \%$ decrease in estimated insulin sensitivity (i.e., Matsuda insulin sensitivity index) and a $23 \%$ increase in insulin resistance derived from HOMA-IR. More importantly, these indices of insulin sensitivity/resistance were not restored after 2 weeks of return to habitual physical activity.

Obesity (112), aging $(113,114)$, and chronic illnesses (114) are all associated with a decrease in the number of steps taken per day and an increase in sedentary time. Concurrently, in a study by Smeuninx et al., older obese and lean individuals showed a significant positive correlation $\left(\mathrm{r}^{2}=0.33\right)$ between average daily step count and the net postprandial myofibrillar protein synthetic response (74). Mutual mechanisms underpin the hypothesis that 


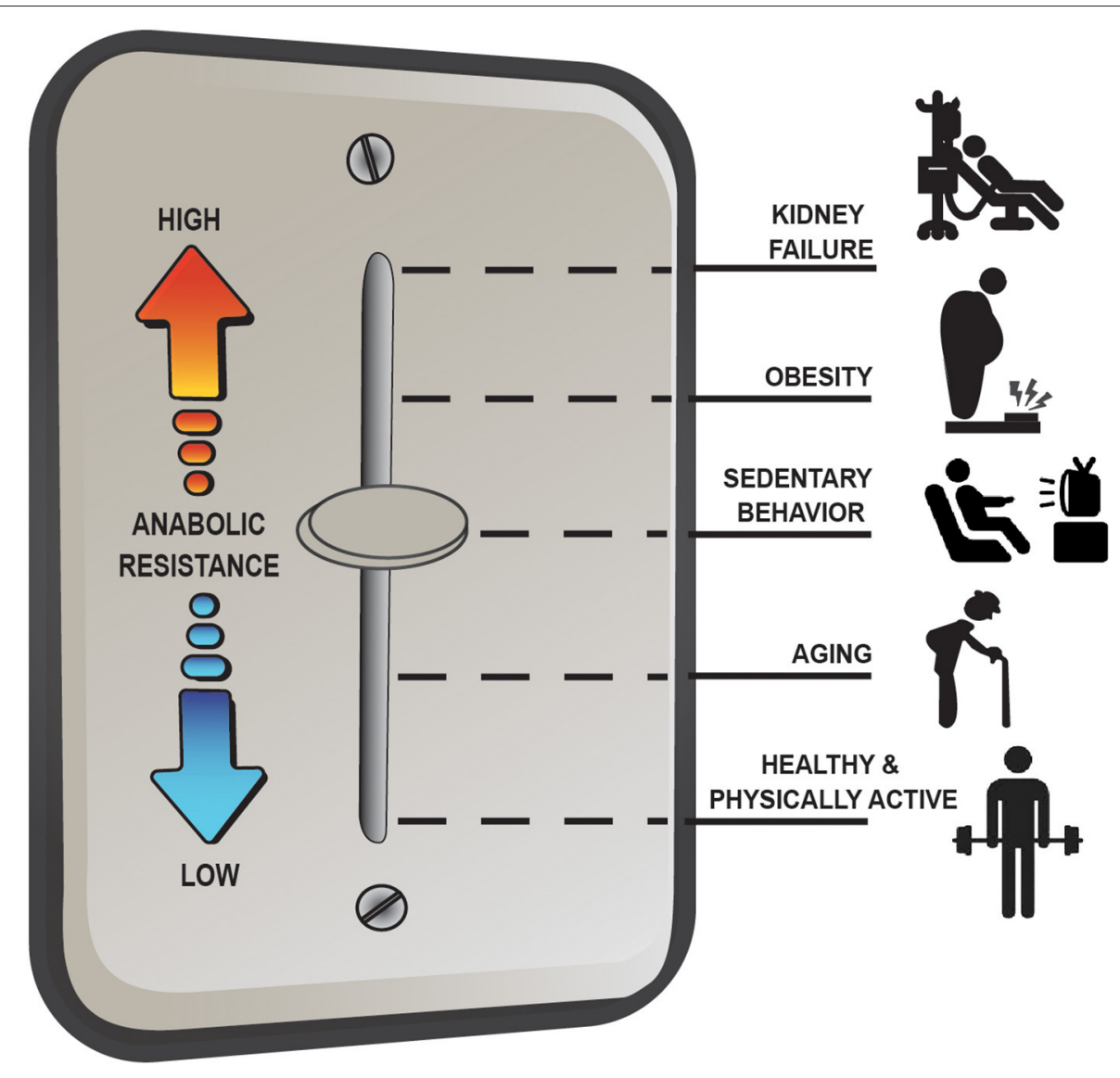

FIGURE 2 | Anabolic resistance of muscle protein synthesis rates (MPS) to dietary amino acids exists as a dimmer switch from low to higher levels. Healthy aging muscle has been shown to be quite responsive to the combined stimuli of feeding and exercise in terms of an MPS response (17), but in absence of prior exercise anabolic resistance is detectable (46). Decreasing the physical activity level, which is perhaps exacerbated further when combining increased sedentary behaviors, increases the level of anabolic resistance on MPS (67). Similarly, obesity increases the level of anabolic resistance, regardless of age (3, 74), with the highest level of anabolic resistance on MPS existing in highly catabolic conditions such as end-stage renal disease (4).

physical inactivity is a critical component of anabolic resistance. The master regulator for MPS mammalian target of rapamycin complex 1 (mTORC1) is clearly reduced during decreases in physical activity, as evidenced by Shad et al. (115) and in line with increased myostatin expression after complete muscle disuse (109). Comparatively, phosphorylation of mTORC1 does not occur in older individuals up to $24 \mathrm{~h}$ after exercise and food ingestion when compared to their younger counterparts (116). The more downstream target, eukaryotic translation initiation factor 4E-binding protein 1 (4E-BP1), showed higher phosphorylation levels after ingesting a meal in habitually active individuals in a study done by Breen et al. (67). In contrast, after 2 weeks of step-reduction those same individuals failed to show an increase in 4E-BP1 activation. Comparatively, our lab has shown an inability to phosphorylate 4E-BP1 after exercise in obese individuals when compared to normal weight individuals (2). Similarly, others have demonstrated that phosphorylation of $4 \mathrm{E}-\mathrm{BP} 1$ does not occur in older individuals up to $24 \mathrm{~h}$ after exercise and food ingestion when compared to their younger counterparts (116).
Skeletal muscle insensitivity to the normally stimulatory effects of dietary amino acids in circulation and exercise contributes significantly to muscle disuse atrophy. This anabolic resistance plays an overt role in the development of agerelated sarcopenia and obesity. The commonality of decreased physical activity/muscle contraction between these conditions is certainly a contributing factor for the associated anabolic resistance. It is still not clear, however, how various forms of sedentary behavior impact anabolic resistance. For example, sedentary behavior refers to low levels of energy expenditure ( $\leq 1.5$ METS) during waking behaviors such as sitting, reclining, or lying (117), and is different from being physically inactive. In other words, individuals can be largely sedentary (i.e., sitting $\geq 8 \mathrm{~h} / \mathrm{d}$ ) (118), but meet the minimal amount of recommended physical activity per week (117). It seems reasonable to assume that breaking up prolonged sedentary blocks of time with socalled "exercise snacks" is likely beneficial for minimizing lower levels of anabolic resistance when compared to experiencing too much sedentary time together throughout the day (119). Moreover, certain populations (such as MHD patients) have a 
higher degree of anabolic resistance that cannot be simply solved by prescribing more physical activity and exercise as discussed previously (103). Instead, this compromised patient condition will require a more comprehensive lifestyle intervention strategy and individualized exercise prescription to overcome MHDrelated anabolic resistance (104).

\section{CONCLUSION}

A central message of this paper has been that anabolic resistance is a common factor underpinning muscle mass loss with aging and other compromised disease states. In an acute setting, targeted exercise prior to protein ingestion has been shown to enhance the dietary amino acid sensitivity of aging muscle (17), and thus is a clear fountain of youth for muscle. The anabolic resistance of myofibrillar protein synthesis rates with obesity (3), at least in our hands, cannot be completely abolished with resistance exercise prior to food intake (2). Instead, we have shown that the dietary amino acid remained confined to the more rapidly turning over sarcoplasmic pool in the post-exercise state (2). Certain catabolic diseases, such as MHD, demonstrate a unique form of anabolic resistance when compared to obesity or aging (4). Specifically, post-absorptive myofibrillar protein synthesis rates are elevated in MHD patient's muscle and create a stimulatory MPS ceiling effect such that dietary amino acids lose their anabolic signaling potential (4). This MHD-related hyper-stimulation of post-absorptive muscle protein turnover likely stems from the accumulation of the inflammatory and/or uremic milieu. As such, we speculate that this catabolic milieu will necessitate a dampening before the effectiveness of targeted

\section{REFERENCES}

1. Janssen I. The epidemiology of sarcopenia. Clin Geriatr Med. (2011) 27:35563. doi: 10.1016/j.cger.2011.03.004

2. Beals JW, Skinner SK, McKenna CF, Poozhikunnel EG, Farooqi SA, van Vliet $\mathrm{S}$, et al. Altered anabolic signalling and reduced stimulation of myofibrillar protein synthesis after feeding and resistance exercise in people with obesity. J Physiol. (2018) 596:5119-33. doi: 10.1113/JP276210

3. Beals JW, Sukiennik RA, Nallabelli J, Emmons RS, Van Vliet S, Young JR, et al. Anabolic sensitivity of postprandial muscle protein synthesis to the ingestion of a protein-dense food is reduced in overweight and obese young adults. Am J Clin Nutr. (2016) 104:1014-22. doi: 10.3945/ajen.116.130385

4. van Vliet S, Skinner SK, Beals JW, Pagni BA, Fang H-Y, Ulanov AV, et al. Dysregulated handling of dietary protein and muscle protein synthesis after mixed-meal ingestion in maintenance hemodialysis patients. Kidney Int Rep. (2018) 3:1403-15. doi: 10.1016/j.ekir.2018.08.001

5. Wall BT, Dirks ML, Snijders T, van Dijk J-W, Fritsch M, Verdijk LB, et al. Short-term muscle disuse lowers myofibrillar protein synthesis rates and induces anabolic resistance to protein ingestion. Am J Physiol Endocrinol Metab. (2016) 310:E137-47. doi: 10.1152/ajpendo.00227.2015

6. Drummond MJ, Dickinson JM, Fry CS, Walker DK, Gundermann DM, Reidy PT, et al. Bed rest impairs skeletal muscle amino acid transporter expression, mTORC1 signaling, and protein synthesis in response to essential amino acids in older adults. Am J Physiol Endocrinol Metab. (2012) 302:E1113-22. doi: 10.1152/ajpendo.00603.2011

7. Askow AT, McKenna CF, Box AG, Khan NA, Petruzzello SJ, De Lisio M, et al. Of sound mind and body: exploring the diet-strength interaction in healthy aging. Front Nutr. (2020) 7:145. doi: 10.3389/fnut.2020.00145 exercise and feeding strategies can be observed in MHD patients (120).

Overall, the anabolic resistance of myofibrillar protein synthesis rates comes in various forms and can differ depending on the population studied. Basic advice such as moving more and eating more protein above the RDA to target the stimulation of post-exercise/postprandial MPS is effective under most situations of anabolic resistance; however, it is not a universal remedy for all situations (e.g., MHD muscle). Instead, there seems to be more of a dimmer switch (Figure 2) for anabolic resistance whereby the level it manifests depends on various factors including habitual physical activity level and dietary patterns, adiposity, and other metabolic abnormalities. For example, aging muscle can remain quite responsive to anabolic signals provided healthy lifestyle strategies are employed (i.e., a lower level of anabolic resistance) whereas MHD muscle is over stimulated at baseline and unresponsive to postprandial (and likely postexercise) anabolic signals (i.e., a high level of anabolic resistance) (17). Research initiatives, such as the NIH Precision Nutrition and the Molecular Transducers of Physical Activity Consortium, will ideally provide better insight into individualized dietary and exercise recommendations to optimize health and quality of life throughout the lifespan and, as such, reduce the prevalence and/or severity of anabolic resistance.

\section{AUTHOR CONTRIBUTIONS}

$\mathrm{NB}, \mathrm{CM}, \mathrm{JB}, \mathrm{KW}$, and KP drafted the manuscript. KP and AS prepared the figures. All authors contributed to manuscript revision, read, and approved the submitted version.

8. Burd NA, McKenna CF, Salvador AF, Paulussen KJ, Moore DR. Dietary protein quantity, quality, and exercise are key to healthy living: a muscle-centric perspective across the lifespan. Front Nutr. (2019) 6:83. doi: 10.3389/fnut.2019.00083

9. Moore DR, Churchward-Venne TA, Witard O, Breen L, Burd NA, Tipton $\mathrm{KD}$, et al. Protein ingestion to stimulate myofibrillar protein synthesis requires greater relative protein intakes in healthy older versus younger men. J Gerontol Series A. (2014). doi: 10.1093/gerona/glu103

10. Pupim LB, Majchrzak KM, Flakoll PJ, Ikizler TA. Intradialytic oral nutrition improves protein homeostasis in chronic hemodialysis patients with deranged nutritional status. J Am Soc Nephrol. (2006) 17:3149-57. doi: 10.1681/ASN.2006040413

11. Wall BT, Snijders T, Senden JM, Ottenbros CL, Gijsen AP, Verdijk LB, et al. Disuse impairs the muscle protein synthetic response to protein ingestion in healthy men. J Clin Endocrinol Metab. (2013) 98:4872-81. doi: $10.1210 /$ jc. $2013-2098$

12. Raj DS, Adeniyi O, Dominic EA, Boivin MA, McClelland S, Tzamaloukas AH, et al. Amino acid repletion does not decrease muscle protein catabolism during hemodialysis. Am J Physiol Endocrinol Metab. (2007) 292:E1534-42. doi: 10.1152/ajpendo.005 99.2006

13. Raj DS, Zager P, Shah VO, Dominic EA, Adeniyi O, Blandon P, et al. Protein turnover and amino acid transport kinetics in end-stage renal disease. Am J Physiol Endocrinol Metab. (2004) 286:E136-43. doi: 10.1152/ajpendo.00352.2003

14. Churchward-Venne TA, Pinckaers PJ, Smeets JS, Betz MW, Senden JM, Goessens JP, et al. Dose-response effects of dietary protein on muscle protein synthesis during recovery from endurance exercise in young men: 
a double-blind randomized trial. The American J Clin Nutr. (2020) 112:30317. doi: $10.1093 /$ ajcn/nqaa 073

15. Moore DR, Robinson MJ, Fry JL, Tang JE, Glover EI, Wilkinson SB, et al. Ingested protein dose response of muscle and albumin protein synthesis after resistance exercise in young men. Am J Clin Nutr. (2009) 89:161-8. doi: 10.3945/ajcn.2008.26401

16. Abou Sawan S, Van Vliet S, Parel JT, Beals JW, Mazzulla M, West DW, et al. Translocation and protein complex co-localization of mTOR is associated with postprandial myofibrillar protein synthesis at rest and after endurance exercise. Physiol Rep. (2018) 6:e13628. doi: 10.14814/phy2.13628

17. Pennings B, Koopman R, Beelen M, Senden JMG, Saris WHM, van Loon LJC. Exercising before protein intake allows for greater use of dietary proteinderived amino acids for de novo muscle protein synthesis in both young and elderly men. Am J Clin Nutr. (2011) 93:322-31. doi: 10.3945/ajcn.2010. 29649

18. Biolo G, Tipton KD, Klein S, Wolfe RR. An abundant supply of amino acids enhances the metabolic effect of exercise on muscle protein. Am J Physiol Endocrinol Metab. (1997) 273:E122-9. doi: 10.1152/ajpendo.1997.273.1.E122

19. Burd NA, Yang Y, Moore DR, Tang JE, Tarnopolsky MA, Phillips SM. Greater stimulation of myofibrillar protein synthesis with ingestion of whey protein isolate v. micellar casein at rest and after resistance exercise in elderly men. Br J Nutr. (2012) 108:958-62. doi: 10.1017/S0007114511006271

20. Tang JE, Moore DR, Kujbida GW, Tarnopolsky MA, Phillips SM. Ingestion of whey hydrolysate, casein, or soy protein isolate: effects on mixed muscle protein synthesis at rest and following resistance exercise in young men. $J$ Appl Physiol. (2009) 107:987-92. doi: 10.1152/japplphysiol.00076.2009

21. Katsanos CS, Kobayashi H, Sheffield-Moore M, Aarsland A, Wolfe RR. A high proportion of leucine is required for optimal stimulation of the rate of muscle protein synthesis by essential amino acids in the elderly. Am J Physiol Endocrinol Metab. (2006) 291:E381-7. doi: 10.1152/ajpendo.0048 8.2005

22. Koopman R, Wagenmakers AJ, Manders RJ, Zorenc AH, Senden JM, Gorselink $\mathrm{M}$, et al. Combined ingestion of protein and free leucine with carbohydrate increases postexercise muscle protein synthesis in vivo in male subjects. Am J Physiol Endocrinol Metab. (2005) 288:E645-53. doi: 10.1152/ajpendo.00413.2004

23. West DW, Burd NA, Coffey VG, Baker SK, Burke LM, Hawley JA, et al. Rapid aminoacidemia enhances myofibrillar protein synthesis and anabolic intramuscular signaling responses after resistance exercise. Am J Clin Nutr. (2011) 94:795-803. doi: 10.3945/ajcn.111.013722

24. Kimball SR, Gordon BS, Moyer JE, Dennis MD, Jefferson LS. Leucine induced dephosphorylation of Sestrin2 promotes mTORC1 activation. Cell Signal. (2016) 28:896-906. doi: 10.1016/j.cellsig.2016.03.008

25. van Vliet S, Smith GI, Porter L, Ramaswamy R, Reeds DN, Okunade AL, et al. The muscle anabolic effect of protein ingestion during a hyperinsulinaemic euglycaemic clamp in middle-aged women is not caused by leucine alone. $J$ Physiol. (2018) 596:4681-92. doi: 10.1113/JP276504

26. Wilkinson DJ, Hossain T, Hill D, Phillips B, Crossland H, Williams J, et al. Effects of leucine and its metabolite $\beta$-hydroxy- $\beta$-methylbutyrate on human skeletal muscle protein metabolism. J Physiol. (2013) 591:2911-23. doi: 10.1113/jphysiol.2013.253203

27. Churchward-Venne TA, Burd NA, Mitchell CJ, West DW, Philp A, Marcotte GR, et al. Supplementation of a suboptimal protein dose with leucine or essential amino acids: effects on myofibrillar protein synthesis at rest and following resistance exercise in men. J Physiol. (2012) 590:2751-65. doi: 10.1113/jphysiol.2012.228833

28. Kobayashi H, Kato H, Hirabayashi Y, Murakami H, Suzuki H. Modulations of muscle protein metabolism by branched-chain amino acids in normal and muscle-atrophying rats. $J$ Nutr. (2006) 136:234S-6S. doi: 10.1093/jn/136.1.234S

29. Burd NA, Beals JW, Martinez IG, Salvador AF, Skinner SK. Foodfirst approach to enhance the regulation of post-exercise skeletal muscle protein synthesis and remodeling. Sports Med. (2019) 49:59-68. doi: 10.1007/s40279-018-1009-y

30. Abou Sawan S, van Vliet S, West DW, Beals JW, Paluska SA, Burd NA, et al. Whole egg, but not egg white, ingestion induces mTOR colocalization with the lysosome after resistance exercise. Am J Physiol Cell Physiol. (2018) 315:C537-43. doi: 10.1152/ajpcell.00225.2018
31. Van Vliet S, Shy EL, Abou Sawan S, Beals JW, West DW, Skinner SK, et al. Consumption of whole eggs promotes greater stimulation of postexercise muscle protein synthesis than consumption of isonitrogenous amounts of egg whites in young men. Am J Clin Nutr. (2017) 106:1401-12. doi: 10.3945/ajcn.117.159855

32. Moore DR, Areta J, Coffey VG, Stellingwerff T, Phillips SM, Burke LM, et al. Daytime pattern of post-exercise protein intake affects whole-body protein turnover in resistance-trained males. Nutr Metab. (2012) 9:1-5. doi: 10.1186/1743-7075-9-91

33. Mamerow MM, Mettler JA, English KL, Casperson SL, Arentson-Lantz E, Sheffield-Moore M, et al. Dietary protein distribution positively influences 24-h muscle protein synthesis in healthy adults. J Nutr. (2014) 144:876-80. doi: $10.3945 /$ jn. 113.185280

34. Phillips SM, Tipton KD, Aarsland A, Wolf SE, Wolfe RR. Mixed muscle protein synthesis and breakdown after resistance exercise in humans. Am J Physiol Endocrinol Metab. (1997) 273:E99-107. doi: 10.1152/ajpendo.1997.273.1.E99

35. Sheffield-Moore M, Yeckel C, Volpi E, Wolf S, Morio B, Chinkes D, et al. Postexercise protein metabolism in older and younger men following moderate-intensity aerobic exercise. Am J Physiol Endocrinol Metab. (2004) 287:E513-22. doi: 10.1152/ajpendo.00334.2003

36. Børsheim E, Tipton KD, Wolf SE, Wolfe RR. Essential amino acids and muscle protein recovery from resistance exercise. Am J Physiol Endocrinol Metab. (2002) 283:E648-57. doi: 10.1152/ajpendo.00466.2001

37. Stokes T, Timmons JA, Crossland H, Tripp TR, Murphy K, McGlory C, et al. Molecular transducers of human skeletal muscle remodeling under different loading states. Cell Rep. (2020) 32:107980. doi: 10.1016/j.celrep.2020.107980

38. Areta JL, Burke LM, Camera DM, West DW, Crawshay S, Moore DR, et al. Reduced resting skeletal muscle protein synthesis is rescued by resistance exercise and protein ingestion following short-term energy deficit. Am J Physiol Endocrinol Metab. (2014) 306:E989-97. doi: 10.1152/ajpendo.00590.2013

39. Gillen JB, West DW, Williamson EP, Fung HJ, Moore DR. Low-carbohydrate training increases protein requirements of endurance athletes. Med Sci Sports Exerc. (2019) 51:2294-301. doi: 10.1249/MSS.0000000000002036

40. Mazzulla M, Sawan SA, Williamson E, Hannaian SJ, Volterman KA, West DW, et al. Protein intake to maximize whole-Body anabolism during postexercise recovery in resistance-trained men with high habitual intakes is severalfold greater than the current recommended dietary allowance. J Nutr. (2020) 150:505-11. doi: 10.1093/jn/nxz249

41. Gorissen SH, Horstman AM, Franssen R, Kouw IW, Wall BT, Burd NA, et al. Habituation to low or high protein intake does not modulate basal or postprandial muscle protein synthesis rates: a randomized trial. Am J Clin Nutr. (2017) 105:332-42. doi: 10.3945/ajcn.115.129924

42. Tinline-Goodfellow CT, West DW, Malowany JM, Gillen JB, Moore DR. An acute reduction in habitual protein intake attenuates post exercise anabolism and may bias oxidation-derived protein requirements in resistance trained men. Front Nutr. (2020) 7:55. doi: 10.3389/fnut.2020.00055

43. Bohé J, Low A, Wolfe RR, Rennie MJ. Human muscle protein synthesis is modulated by extracellular, not intramuscular amino acid availability: a dose-response study. J Physiol. (2003) 552(Pt 1):315-24. doi: 10.1113/jphysiol.2003.050674

44. Bohé J, Low JF, Wolfe RR, Rennie MJ. Latency and duration of stimulation of human muscle protein synthesis during continuous infusion of amino acids. J Physiol. (2001) 532(Pt 2):575-9. doi: 10.1111/j.1469-7793.2001.0575f.x

45. Cuthbertson D, Smith K, Babraj J, Leese G, Waddell T, Atherton P, et al. Anabolic signaling deficits underlie amino acid resistance of wasting, aging muscle. FASEB J. (2005) 19:422-4. doi: 10.1096/fj.04-2640fje

46. Wall BT, Gorissen SH, Pennings B, Koopman R, Groen BB, Verdijk LB, et al. Aging is accompanied by a blunted muscle protein synthetic response to protein ingestion. PLoS ONE. (2015) 10:e0140903. doi: 10.1371/journal.pone.0140903

47. Markofski MM, Dickinson JM, Drummond MJ, Fry CS, Fujita S, Gundermann DM, et al. Effect of age on basal muscle protein synthesis and mTORC1 signaling in a large cohort of young and older men and women. Exp Gerontol. (2015) 65:1-7. doi: 10.1016/j.exger.2015.02.015

48. Katsanos CS, Kobayashi H, Sheffield-Moore M, Aarsland A, Wolfe RR. Aging is associated with diminished accretion of muscle proteins after the ingestion 
of a small bolus of essential amino acids. Am J Clin Nutr. (2005) 82:1065-73. doi: $10.1093 / \mathrm{ajcn} / 82.5 .1065$

49. Gorissen SH, Trommelen J, Kouw IW, Holwerda AM, Pennings B, Groen BB, et al. Protein type, protein dose, and age modulate dietary protein digestion and phenylalanine absorption kinetics and plasma phenylalanine availability in humans. J Nutr. (2020) 150:2041-50. doi: 10.1093/jn/nxaa024

50. Wall BT, Hamer HM, de Lange A, Kiskini A, Groen BB, Senden JM, et al. Leucine co-ingestion improves post-prandial muscle protein accretion in elderly men. Clin Nutr. (2013) 32:412-9. doi: 10.1016/j.clnu.2012.09.002

51. Pennings B, Groen B, de Lange A, Gijsen AP, Zorenc AH, Senden JM, et al. Amino acid absorption and subsequent muscle protein accretion following graded intakes of whey protein in elderly men. Am J Physiol Endocrinol Metab. (2012) 302:E992-9. doi: 10.1152/ajpendo.00517.2011

52. Yang Y, Breen L, Burd NA, Hector AJ, Churchward-Venne TA, Josse AR, et al. Resistance exercise enhances myofibrillar protein synthesis with graded intakes of whey protein in older men. Br J Nutr. (2012) 108:1780-8. doi: $10.1017 /$ S0007114511007422

53. Pennings B, Groen BB, van Dijk J-W, de Lange A, Kiskini A, Kuklinski M, et al. Minced beef is more rapidly digested and absorbed than beef steak, resulting in greater postprandial protein retention in older men. Am J Clin Nutr. (2013) 98:121-8. doi: 10.3945/ajcn.112.051201

54. Smith GI, Atherton P, Reeds DN, Mohammed BS, Rankin D, Rennie MJ, et al. Dietary omega-3 fatty acid supplementation increases the rate of muscle protein synthesis in older adults: a randomized controlled trial. Am J Clin Nutr. (2011) 93:402-12. doi: 10.3945/ajcn.110.005611

55. Bell KE, Snijders T, Zulyniak M, Kumbhare D, Parise G, Chabowski A, et al. A whey protein-based multi-ingredient nutritional supplement stimulates gains in lean body mass and strength in healthy older men: a randomized controlled trial. PLoS ONE. (2017) 12:e0181387. doi: 10.1371/journal.pone. 0181387

56. Kouw IW, Holwerda AM, Trommelen J, Kramer IF, Bastiaanse J, Halson SL, et al. Protein ingestion before sleep increases overnight muscle protein synthesis rates in healthy older men: a randomized controlled trial. J Nutr. (2017) 147:2252-61. doi: 10.3945/jn.117.254532

57. Rafii M, Chapman K, Elango R, Campbell WW, Ball RO, Pencharz PB, et al. Dietary protein requirement of men $>65$ years old determined by the indicator amino acid oxidation technique is higher than the current estimated average requirement. J Nutr. (2015) 146:681-7. doi: 10.3945/jn.115.225631

58. Houston DK, Nicklas BJ, Ding J, Harris TB, Tylavsky FA, Newman $\mathrm{AB}$, et al. Dietary protein intake is associated with lean mass change in older, community-dwelling adults: the Health, Aging, and Body Composition (Health ABC) Study. Am J Clin Nutr. (2008) 87:150-5. doi: 10.1093/ajcn/87.1.150

59. Szwiega S, Pencharz PB, Rafii M, Lebarron M, Chang J, Ball RO, et al. Dietary leucine requirement of older men and women is higher than current recommendations. Am J Clin Nutr. (2020) 113:410-9. doi: 10.1093/ajcn/nqaa323

60. Kumar V, Selby A, Rankin D, Patel R, Atherton P, Hildebrandt W, et al. Age-related differences in the dose-response relationship of muscle protein synthesis to resistance exercise in young and old men. J Physiol. (2009) 587:211-7. doi: 10.1113/jphysiol.2008.164483

61. Durham WJ, Casperson SL, Dillon EL, Keske MA, Paddon-Jones D, Sanford AP, et al. Age-related anabolic resistance after endurance-type exercise in healthy humans. FASEB J. (2010) 24:4117-27. doi: 10.1096/fj.09-1 50177

62. Snijders T, Nederveen JP, Joanisse S, Leenders M, Verdijk LB, Van Loon LJ, et al. Muscle fibre capillarization is a critical factor in muscle fibre hypertrophy during resistance exercise training in older men. $J$ Cachexia Sarcopenia Muscle. (2017) 8:267-76. doi: 10.1002/jcsm.12137

63. Moro T, Brightwell CR, Phalen DE, McKenna CF, Lane SJ, Porter C, et al. Low skeletal muscle capillarization limits muscle adaptation to resistance exercise training in older adults. Exp Gerontol. (2019) 127:110723. doi: 10.1016/j.exger.2019.110723

64. Peterson MD, Sen A, Gordon PM. Influence of resistance exercise on lean body mass in aging adults: a meta-analysis. Med Sci Sports Exerc. (2011) 43:249-58. doi: 10.1249/MSS.0b013e3181eb6265
65. Borde R, Hortobagyi T, Granacher U. Dose-response relationships of resistance training in healthy old adults: a systematic review and metaanalysis. Sports Med. (2015) 45:1693-720. doi: 10.1007/s40279-015-0385-9

66. Kumar V, Atherton PJ, Selby A, Rankin D, Williams J, Smith K, et al. Muscle protein synthetic responses to exercise: effects of age, volume, and intensity. J Gerontol Ser A Biomed Sci Med Sci. (2012) 67:1170-7. doi: 10.1093/gerona/gls141

67. Breen L, Stokes KA, Churchward-Venne TA, Moore DR, Baker SK, Smith $\mathrm{K}$, et al. Two weeks of reduced activity decreases leg lean mass and induces "anabolic resistance" of myofibrillar protein synthesis in healthy elderly. $J$ Clin Endocrinol Metab. (2013) 98:2604-12. doi: 10.1210/jc.2013-1502

68. Harvey JA, Chastin SF, Skelton DA. Prevalence of sedentary behavior in older adults: a systematic review. Int J Environ Res Public Health. (2013) 10:6645-61. doi: 10.3390/ijerph10126645

69. Brook MS, Wilkinson DJ, Mitchell WK, Lund JN, Phillips BE, Szewczyk NJ, et al. Synchronous deficits in cumulative muscle protein synthesis and ribosomal biogenesis underlie age-related anabolic resistance to exercise in humans. J Physiol. (2016) 594:7399-417. doi: 10.1113/JP272857

70. Suetta C, Frandsen U, Mackey AL, Jensen L, Hvid LG, Bayer ML, et al. Ageing is associated with diminished muscle re-growth and myogenic precursor cell expansion early after immobility-induced atrophy in human skeletal muscle. J Physiol. (2013) 591:3789-804. doi: 10.1113/jphysiol.2013.257121

71. English KL, Paddon-Jones D. Protecting muscle mass and function in older adults during bed rest. Curr Opin Clin Nutr Metab Care. (2010) 13:34-9. doi: 10.1097/MCO.0b013e328333aa66

72. Guillet C, Delcourt I, Rance M, Giraudet C, Walrand S, Bedu M, et al. Changes in basal and insulin and amino acid response of whole body and skeletal muscle proteins in obese men. J Clin Endocrinol Metab. (2009) 94:3044-50. doi: 10.1210/jc.2008-2216

73. Murton AJ, Marimuthu K, Mallinson JE, Selby AL, Smith K, Rennie MJ, et al. Obesity appears to be associated with altered muscle protein synthetic and breakdown responses to increased nutrient delivery in older men, but not reduced muscle mass or contractile function. Diabetes. (2015) 64:3160-71. doi: $10.2337 / \mathrm{db} 15-0021$

74. Smeuninx B, McKendry J, Wilson D, Martin U, Breen L. Age-related anabolic resistance of myofibrillar protein synthesis is exacerbated in obese inactive individuals. J Clin Endocrinol Metab. (2017) 102:3535-45. doi: 10.1210/jc.2017-00869

75. Tran L, Kras KA, Hoffman N, Ravichandran J, Dickinson JM, D'Lugos A, et al. Lower fasted-state but greater increase in muscle protein synthesis in response to elevated plasma amino acids in obesity. Obesity. (2018) 26:1179-87. doi: 10.1002/oby.22213

76. Beals JW, Mackenzie RW, Van Vliet S, Skinner SK, Pagni BA, Niemiro GM, et al. Protein-rich food ingestion stimulates mitochondrial protein synthesis in sedentary young adults of different BMIs. J Clin Endocrinol Metab. (2017) 102:3415-24. doi: 10.1210/jc.2017-00360

77. Chevalier S, Burgos SA, Morais JA, Gougeon R, Bassil M, Lamarche $\mathrm{M}$, et al. Protein and glucose metabolic responses to hyperinsulinemia, hyperglycemia, and hyperaminoacidemia in obese men. Obesity. (2015) 23:351-8. doi: 10.1002/oby.20943

78. Kouw IW, van Dijk JW, Horstman AM, Kramer IF, Goessens JP, van Dielen FM, et al. Basal and postprandial myofibrillar protein synthesis rates do not differ between lean and obese middle-aged men. J Nutr. (2019) 149:1533-42. doi: 10.1093/jn/nxz104

79. Beals JW, Burd NA, Moore DR, van Vliet S. Obesity alters the muscle protein synthetic response to nutrition and exercise. Front Nutr. (2019) 6:87. doi: $10.3389 /$ fnut.2019.00087

80. Williamson DL, Dungan CM, Mahmoud AM, Mey JT, Blackburn BK, Haus JM. Aberrant REDD1-mTORC1 responses to insulin in skeletal muscle from Type 2 diabetics. Am J Physiol Regul Integrative Compar Physiol. (2015) 309:R855-63. doi: 10.1152/ajpregu.00285.2015

81. Bosy-Westphal A, Kossel E, Goele K, Later W, Hitze B, Settler U, et al. Contribution of individual organ mass loss to weight loss-associated decline in resting energy expenditure. Am J Clin Nutr. (2009) 90:993-1001. doi: $10.3945 /$ ajcn.2008.27402

82. Paris HL, Foright RM, Werth KA, Larson LC, Beals JW, Cox-York K, et al. Increasing energy flux to decrease the biological drive toward weight regain 
after weight loss-a proof-of-concept pilot study. Clin Nutr. (2016) 11:e12-20. doi: 10.1016/j.clnesp.2015.11.005

83. Hernández-Reyes A, Cámara-Martos F, Molina-Luque R, Romero-Saldaña M, Molina-Recio G, Moreno-Rojas R. Changes in body composition with a hypocaloric diet combined with sedentary, moderate and high-intense physical activity: a randomized controlled trial. BMC Women's Health. (2019) 19:167. doi: 10.1186/s12905-019-0864-5

84. Wilkinson SB, Phillips SM, Atherton PJ, Patel R, Yarasheski KE, Tarnopolsky MA, et al. Differential effects of resistance and endurance exercise in the fed state on signalling molecule phosphorylation and protein synthesis in human muscle. J Physiol. (2008) 586:3701-17. doi: 10.1113/jphysiol.2008.153916

85. Hulston CJ, Woods RM, Dewhurst-Trigg R, Parry SA, Gagnon S, Baker L, et al. Resistance exercise stimulates mixed muscle protein synthesis in lean and obese young adults. Physiol Rep. (2018) 6:e13799. doi: 10.14814/phy2.13799

86. Hector AJ, Marcotte GR, Churchward-Venne TA, Murphy CH, Breen $\mathrm{L}$, von Allmen $\mathrm{M}$, et al. Whey protein supplementation preserves postprandial myofibrillar protein synthesis during short-term energy restriction in overweight and obese adults. $J$ Nutr. (2015) 145:246-52. doi: 10.3945/jn.114.200832

87. Hector AJ, McGlory C, Damas F, Mazara N, Baker SK, Phillips SM. Pronounced energy restriction with elevated protein intake results in no change in proteolysis and reductions in skeletal muscle protein synthesis that are mitigated by resistance exercise. FASEB J. (2018) 32:265-75. doi: 10.1096/fj.201700158RR

88. Smith GI, Yoshino J, Kelly SC, Reeds DN, Okunade A, Patterson BW, et al. High-protein intake during weight loss therapy eliminates the weight-lossinduced improvement in insulin action in obese postmenopausal women. Cell Rep. (2016) 17:849-61. doi: 10.1016/j.celrep.2016.09.047

89. Anker SD, Coats AJ, Morley JE, Rosano G, Bernabei R, von Haehling S, et al. Muscle wasting disease: a proposal for a new disease classification. J Cachexia Sarcopenia Muscle. (2014) 5:1-3. doi: 10.1007/s13539-014-0135-0

90. Fearon K, Strasser F, Anker SD, Bosaeus I, Bruera E, Fainsinger RL, et al. Definition and classification of cancer cachexia: an international consensus. Lancet Oncol. (2011) 12:489-95. doi: 10.1016/S1470-2045(10)70218-7

91. Emery PW, Edwards RH, Rennie MJ, Souhami RL, Halliday D. Protein synthesis in muscle measured in vivo in cachectic patients with cancer. $\mathrm{Br}$ Med J. (1984) 289:584-6. doi: 10.1136/bmj.289.6445.584

92. Williams JP, Phillips BE, Smith K, Atherton PJ, Rankin D, Selby AL, et al. Effect of tumor burden and subsequent surgical resection on skeletal muscle mass and protein turnover in colorectal cancer patients. Am J Clin Nutr. (2012) 96:1064-70. doi: 10.3945/ajcn.112.045708

93. Deutz NE, Safar A, Schutzler S, Memelink R, Ferrando A, Spencer H, et al. Muscle protein synthesis in cancer patients can be stimulated with a specially formulated medical food. Clin Nutr. (2011) 30:759-68. doi: 10.1016/j.clnu.2011.05.008

94. Hendriks F, Smeets J, Broers N, Van Kranenburg J, van der Sande F, Kooman J, et al. Amino acid loss during hemodialysis in end-stage renal disease patients. Clin Nutr. (2018) 37:S96. doi: 10.1016/j.clnu.2018. 06.1372

95. Horstman AM, Olde Damink SW, Schols AM, van Loon LJ. Is cancer cachexia attributed to impairments in basal or postprandial muscle protein metabolism? Nutrients. (2016) 8:499. doi: 10.3390/nu8080499

96. Raj DS, Dominic EA, Wolfe R, Shah VO, Bankhurst A, Zager PG, et al. Coordinated increase in albumin, fibrinogen, and muscle protein synthesis during hemodialysis: role of cytokines. Am J Physiol Endocrinol Metab. (2004) 286:E658-64. doi: 10.1152/ajpendo.00444.2003

97. Pupim LB, Flakoll PJ, Brouillette JR, Levenhagen DK, Hakim RM, Ikizler TA. Intradialytic parenteral nutrition improves protein and energy homeostasis in chronic hemodialysis patients. J Clin Invest. (2002) 110:48392. doi: 10.1172/JCI0215449

98. Veeneman JM, Kingma HA, Boer TS, Stellaard F, De Jong PE, Reijngoud DJ, et al. Protein intake during hemodialysis maintains a positive whole body protein balance in chronic hemodialysis patients. Am J Physiol Endocrinol Metab. (2003) 284:E954-65. doi: 10.1152/ajpendo.00264.2002

99. Weiner DE, Tighiouart H, Ladik V, Meyer KB, Zager PG, Johnson DS. Oral intradialytic nutritional supplement use and mortality in hemodialysis patients. Am J Kidney Dis. (2014) 63:276-85. doi: 10.1053/j.ajkd.2013. 08.007
100. Lacson E Jr, Wang W, Zebrowski B, Wingard R, Hakim RM. Outcomes associated with intradialytic oral nutritional supplements in patients undergoing maintenance hemodialysis: a quality improvement report. Am J Kidney Dis. (2012) 60:591-600. doi: 10.1053/j.ajkd.2012.04.019

101. Benner D, Brunelli SM, Brosch B, Wheeler J, Nissenson AR. Effects of oral nutritional supplements on mortality, missed dialysis treatments, and nutritional markers in hemodialysis patients. J Ren Nutr. (2018) 28:191-6. doi: 10.1053/j.jrn.2017.10.002

102. Caglar K, Fedje L, Dimmitt R, Hakim RM, Shyr Y, Ikizler TA. Therapeutic effects of oral nutritional supplementation during hemodialysis. Kidney Int. (2002) 62:1054-9. doi: 10.1046/j.1523-1755.2002.00530.x

103. McKenna CF, Salvador AF, Hendriks FK, Harris APY, van Loon LJC, Burd NA. Exercising to offset muscle mass loss in hemodialysis patients: the disconnect between intention and intervention. Semin Dial. (2019) 32:37985. doi: $10.1111 /$ sdi. 12805

104. Wilund KR, Viana JL, Perez LM. A critical review of exercise training in hemodialysis patients: personalized activity prescriptions are needed. Exerc Sport Sci Rev. (2020) 48:28-39. doi: 10.1249/JES.0000000000000209

105. Draicchio F, van Vliet S, Ancu O, Paluska SA, Wilund KR, Mickute M, et al. Integrin-associated ILK and PINCH1 protein content are reduced in skeletal muscle of maintenance haemodialysis patients. J Physiol. (2020) 598:5701-16. doi: 10.1113/JP280441

106. Wilund $\mathrm{K}$, Thompson S, Bennett PN. A global approach to increasing physical activity and exercise in kidney care: the International Society of Renal Nutrition and Metabolism Global Renal Exercise Group. J Renal Nutr. (2019) 29:467-70. doi: 10.1053/j.jrn.2019.08.004

107. Ferrando AA, Lane HW, Stuart CA, Davis-Street J, Wolfe RR. Prolonged bed rest decreases skeletal muscle and whole body protein synthesis. Am J Physiol. (1996) 270(4 Pt 1):E627-33. doi: 10.1152/ajpendo.1996.270. 4.E627

108. Phillips SM, Glover EI, Rennie MJ. Alterations of protein turnover underlying disuse atrophy in human skeletal muscle. J Appl Physiol. (2009) 107:645-54. doi: 10.1152/japplphysiol.00452.2009

109. Wall BT, Dirks ML, Snijders T, Senden JM, Dolmans J, van Loon LJ. Substantial skeletal muscle loss occurs during only 5 days of disuse. Acta Physiol. (2014) 210:600-11. doi: 10.1111/apha.12190

110. Kilroe SP, Fulford J, Holwerda AM, Jackman SR, Lee BP, Gijsen AP, et al. Short-term muscle disuse induces a rapid and sustained decline in daily myofibrillar protein synthesis rates. Am J Physiol Endocrinol Metab. (2020) 318:E117-30. doi: 10.1152/ajpendo.00360.2019

111. McGlory C, von Allmen MT, Stokes T, Morton RW, Hector AJ, Lago BA, et al. Failed recovery of glycemic control and myofibrillar protein synthesis with 2 wk of physical inactivity in overweight, prediabetic older adults. J Gerontol Series A. (2018) 73:1070-7. doi: 10.1093/gerona/glx203

112. de Rooij BH, van der Berg JD, van der Kallen CJ, Schram MT, Savelberg HH, Schaper NC, et al. Physical activity and sedentary behavior in metabolically healthy versus unhealthy obese and non-obese individuals-the Maastricht study. PLoS ONE. (2016) 11:e0154358. doi: 10.1371/journal.pone.01 54358

113. Tudor-Locke C, Schuna JM Jr, Barreira TV, Mire EF, Broyles ST, Katzmarzyk PT, et al. Normative steps/day values for older adults: NHANES 2005-2006. J Gerontol Ser A Biomed Sci Med Sci. (2013) 68:1426-32. doi: $10.1093 /$ gerona/glt116

114. Tudor-Locke C, Craig CL, Aoyagi Y, Bell RC, Croteau KA, De Bourdeaudhuij I, et al. How many steps/day are enough? For older adults and special populations. Int J Behav Nutr Phys Activity. (2011) 8:80. doi: $10.1186 / 1479-5868-8-80$

115. Shad BJ, Thompson JL, Holwerda AM, Stocks B, Elhassan YS, Philp $A$, et al. One week of step reduction lowers myofibrillar protein synthesis rates in young men. Med Sci Sports Exer. (2019) 2019:2125-34. doi: 10.1249/MSS.0000000000002034

116. Fry CS, Drummond MJ, Glynn EL, Dickinson JM, Gundermann DM, Timmerman KL, et al. Aging impairs contraction-induced human skeletal muscle mTORC1 signaling and protein synthesis. Skeletal Muscle. (2011) 1:1-11. doi: 10.1186/2044-5040-1-11

117. Piercy KL, Troiano RP, Ballard RM, Carlson SA, Fulton JE, Galuska DA, et al. The physical activity guidelines for Americans. JAMA. (2018) 320:2020-8. doi: 10.1001/jama.2018.14854 
118. Ekelund U, Steene-Johannessen J, Brown WJ, Fagerland MW, Owen $\mathrm{N}$, Powell KE, et al. Does physical activity attenuate, or even eliminate, the detrimental association of sitting time with mortality? A harmonised meta-analysis of data from more than 1 million men and women. Lancet. (2016) 388:1302-10. doi: 10.1016/S0140-6736(16) 30370-1

119. Gillen JB, Estafanos S, Williamson E, Hodson N, Malowany JM, Kumbhare DA, et al. Interrupting prolonged sitting with repeated chair stands or short walks reduces postprandial insulinemia in healthy adults. J Appl Physiol. (2020) 130:104-13. doi: 10.1152/japplphysiol.0079 6.2020

120. Jeong JH, Biruete A, Tomayko EJ, Wu PT, Fitschen P, Chung HR, et al. Results from the randomized controlled IHOPE trial suggest no effects of oral protein supplementation and exercise training on physical function in hemodialysis patients. Kidney Int. (2019) 96:777-86. doi: 10.1016/j.kint.2019.03.018
Conflict of Interest: NB has received research grants, consulting fees, and speaking honoraria from Dairy Management Inc. (DMI), the National Cattlemen's Beef Association, and Alliance for Potato Research and Education (APRE). This work was supported, in part, by the NIH training grant T32 HL130357 to JB.

The remaining authors declare that the research was conducted in the absence of any commercial or financial relationships that could be construed as a potential conflict of interest.

Copyright (c) 2021 Paulussen, McKenna, Beals, Wilund, Salvador and Burd. This is an open-access article distributed under the terms of the Creative Commons Attribution License (CC BY). The use, distribution or reproduction in other forums is permitted, provided the original author(s) and the copyright owner(s) are credited and that the original publication in this journal is cited, in accordance with accepted academic practice. No use, distribution or reproduction is permitted which does not comply with these terms. 